\title{
Pengaruh Knowledge, Motivasi dan Keterlibatan terhadap Minat Mahasiswa dalam Program ITS Smart Eco Campus
}

\author{
Yulintika T., Gunawan J., dan Noer B. A. \\ Departemen Manajemen Bisnis, Fakultas Bisnis dan Manajemen Teknologi, \\ Institut Teknologi Sepuluh Nopember (ITS) \\ e-mail: tussyyulintika@gmail.com
}

\begin{abstract}
Abstrak-Institut Teknologi Sepuluh Nopember (ITS) merupakan perguruan tinggi di Indonesia yang telah menerapkan program eco campus. Program ITS Smart Eco Campus merupakan salah satu bagian dari perencanaan strategis ITS dalam mewujudkan kampus yang peduli dan berbudaya lingkungan dengan melakukan pengelolaan lingkungan secara sistematis, berkelanjutan dan berkesinambungan dengan berpedoman pada Tri Dharma Perguruan Tinggi. Tujuan dilakukan penelitian ini adalah untuk mempelajari pengaruh pengetahuan terhadap minat mahasiswa, motivasi terhadap minat mahasiswa dan keterlibatan terhadap minat mahasiswa, serta pengaruh simultan antara pengetahuan, motivasi dan keterlibatan terhadap minat mahasiswa. Populasi dalam penelitian ini adalah mahasiswa ITS. Sedangkan sampel penelitian adalah 393 mahasiswa kampus ITS Sukolilo, sesuai dengan rumus Slovin, didapatkan 12 departemen dan 8 fakutas, dari 38 departemen dan 10 fakultas yang ada. Analisis data dalam penelitian ini dilakukan dengan analisis regresi linier berganda. Program penelitian menunjukkan bahwa pengetahuan berpengaruh positif terhadap minat mahasiswa dalam program ITS Smart Eco Campus; motivasi berpengaruh positif terhadap minat mahasiswa dalam program ITS Smart Eco Campus; keterlibatan berpengaruh positif terhadap minat mahasiswa dalam program ITS Smart Eco Campus; serta pengetahuan, motivasi dan keterlibatan secara simultan berpengaruh terhadap minat mahasiswa dalam program ITS Smart Eco Campus.
\end{abstract}

Kata Kunci-Eco Campus, Keterlibatan, Knowledge, Minat, Motivasi

\section{PENDAHULUAN}

$\mathrm{D}$ ALAM beberapa tahun terakhir, isu pelestarian lingkungan hidup merupakan isu global penting yang bersifat sistematik, rumit, kompleks, dan memiliki cakupan yang cukup luas. Permasalahan ini menjadi perhatian utama dari berbagai program yang dilaksanakan oleh pemerintah, swasta maupun lembaga swadaya masyarakat. Namun pada praktiknya, permasalahan ini masih belum teratasi secara maksimal sena dibutuhkan suatu prinsip dan tindakan yang dapat memancutu 1 aktivitas manusia menuju pembangunan khususnya 2 pembangunan dalam hal pelestarian lingkungan. Jalur yang 3 dapat digunakan untuk menyalurkan prinsip, nilai-nilai, 4 tindakan dan tanggung jawab sosial yaitu melalui jalur 6 pendidikan.

Salah satu jenis institusi pendidikan yang dapat secara 8 langsung mengaplikasikan secara praktik adalah institusi 9 perguruan tinggi. Tingkat pendidikan di lingkup pera tinggi atau kampus dianggap memiliki potensi dan peranan penting dalam menjawab berbagai problematika termasuk persoalan lingkungan hidup. Program lingkungan yang akhir-akhir ini ditujukan untuk mengembangkan dan mewujudkan upaya pelestarian lingkungan melalui konsep kawasan kampus yang berwawasan lingkungan adalah eco campus/green campus.

Konsep eсо campus merupakan konsep pengelolaan yang dikembangkan oleh komunitas institusi untuk mewujudkan lingkungan kampus hijau dan berwawasan lingkungan dengan mengedepankan konservasi, penghematan (reduce, reuse, recycle), dan penanganan yang baik, sehat, serta berwawasan lingkungan [2]. Cara untuk mengetahui mengenai informasi perguruan tinggi yang telah menerapkan konsep eco campus yaitu dengan mengeksesnya lewat informasi yang dimiliki oleh UI GreenMetric.

UI GreenMetric merupakan sebuah kompetisi berskala internasional yang menilai universitas dalam segi kontribusi nyata dalam pelestarian lingkungan atau sebagai tolak ukur (rating system) untuk mengurutkan usaha sustainability kampus-kampus di dunia dengan indeks angka dan metodologi tertentu (UI Green Metrics, 2015). Terdapat enam kategori penilaian green campus/eco campus dalam Greenmetric, yaitu setting and infrastructure, energy and climate change, waste, water, transportation dan education. Menurut data UI GeenMetric (2015), terdapat beberapa perguruan tinggi di Indonesia yang sudah menerapkan program eco campus dan memperoleh peringkat dalam kampus hijau dunia salah satunya adalah Institut Teknologi Sepuluh Nopember.

Pada ranking UI GeenMetric dalam region asia pada tahun 2017, Universitas Indonesia (UI) ada di peringkat 2 dengan nilai 6.519, diikuti oleh Bogor Agricultural University di peringkat 9 dengan nilai 6.076, dan Institut Teknologi Sepuluh Nopember di peringkat 11 dengan nilai 6.059. Berikut disajikan tentang 10 perguruan tinggi di Indonesia yang berada di peringkat teratas menurut UI GreenMetric:

Tabel 1 .

Sepuluh Perguruan Tinggi di Indonesia yang Memperoleh Peringkat Kampus Hijau Dunia

\begin{tabular}{lc}
\multicolumn{1}{c}{ Nama Perguruan Tinggi } & Skor Total \\
\hline Universitas Indonesia & 6.519 \\
Institut Pertanian Bogor & 6.076 \\
Institut Teknologi Sepuluh Nopember & 6.059 \\
Universitas Negeri Semarang & 5.785 \\
Universitas Sebelas Maret & 5.729 \\
Universitas Diponegoro & 5.643 \\
Universitas Brawijaya & 5.191 \\
Universitas Islam Indonesia & 5.171 \\
Telkom University & 5.116 \\
Universitas Padjajaran & 5.101 \\
\hline
\end{tabular}

Sumber: UI GreenMetrics (2017)

Berdasarkan tabel di atas, diketahui bahwa terdapat sepuluh perguruan tinggi di Indonesia yang masuk dalam peringkat teratas dalam UI GreenMetrics. Peringkat pertama 
yaitu Universitas Indonesia dengan skor total 6.519. Peringkat kedua yaitu Institut Pertanian Bogor dengan skor total 6.076. Peringkat ketiga yaitu Institut Teknologi Sepuluh Nopember dengan skor total 6.059 [1]. Peringkat keempat yaitu Universitas Negeri Semarang dengan skor total 5.785. Peringkat kelima yaitu Universitas Sebelas Maret dengan skor total 5.729. Peringkat keenam yaitu Universitas Diponegoro dengan skor total 5.643. Peringkat ketujuh yaitu Universitas Brawijaya dengan skor total 5.191. Peringkat kedelapan yaitu Universitas Islam Indonesia dengan skor total 5.171. Peringkat kesembilan yaitu Telkom University dengan skor total 5.116. Peringkat kesepuluh yaitu Universitas Padjajaran dengan skor total 5.101. Tabel di atas juga menunjukkan bahwa dalam peringkat nasional, Universitas Indonesia berada pada posisi puncak dan Institut Teknologi Sepuluh Nopember berada di peringkat ke 3 [1].

ITS merupakan perguruan tinggi yang terletak di Kota Surabaya dan telah menerapkan program eco campus yang diberi nama ITS Smart Eco Campus. ITS Smart Eco Campus merupakan bagian dari perencanaan strategis ITS dalam mewujudkan kampus yang peduli dan berbudaya lingkungan dengan melakukan pengelolaan lingkungan secara sistematis, konsisten dan berkesinambungan dengan berpedoman pada Tri Dharma Perguruan Tinggi. Terdapat lima aspek dalam penerapan ITS Smart Eco Campus yaitu green transport (transportasi ramah lingkungan), energy (energi), waste (sampah), water (air), dan keanekaragaman hayati [2].

Bentuk dari program ITS Smart Eco Campus adalah kegiatan penghijauan dan perluasan hutan kampus atau yang bisa disebut dengan gugur gunung (GG). Hutan kampus yang sudah ada di ITS akan ditingkatkan fungsinya berdasarkan fungsi konservasi dan budidaya serta mengembangkan tanaman langka seperti juwet, kecacil, gebang atau jenis tanaman dan pohon langka lain. Total lahan ITS sebesar 158 hektare dimaksimalkan demi kelestarian lingkungan. Selain itu, dilibatkan 7.000 warga ITS, dosen, karyawan dan seluruh mahasiswa yang ada.

Pada beberapa tahun ke depan, infrastruktur yang berkonsep green building tersebut sudah dapat diimplementasikan di lingkungan ITS, seperti pada desain standar green building, green infrastructur serta sistem drainase yang ramah lingkungan. Masterplan berbasis eco campus diadopsi untuk mencegah pemborosan energi di ITS. Setiap tahunnya ITS harus membayar enam miliar untuk listrik dan pemakaian air bersih tiap tahun menghabiskan biaya sebesar tiga koma enam miliar. Terkait demikian, akan banyak program ITS Smart Eco Campus untuk menciptakan budaya lingkungan dan ITS akan memprioritaskan program ITS Smart Eco Campus [2].

Temuan awal peneliti menunjukkan bahwa tidak semua mahasiswa ITS mengetahui tentang program ITS Smart Eco Campus. Knowledge dianggap sebagai cakupan seluruh informasi akurat yang disimpan dalam memori seseorang yang sama baiknya dengan persepsi terhadap pengetahuan suatu hal [3]. Knowledge mahasiswa ITS pada program ITS Smart Eco Campus dapat dilihat dari adanya manfaat program ITS Smart Eco Campus, tujuan program ITS Smart Eco Campus, kegiatan-kegiatan yang dilakukan program ITS Smart Eco Campus serta implikasi program ITS Smart Eco Campus pada mahasiswa ITS. Selain itu, temuan awal peneliti juga menunjukkan bahwa motivasi mahasiswa mahasiswa dalam program ITS Smart Eco Campus juga kurang. Hal ini dibuktikan dengan sedikitnya mahasiswa yang ikut dalam kegiatan gugur gunung. Pada sisi lain, peneliti juga menemukan bahwa tidak semua mahasiswa ITS yang terlibat dalam program ITS Smart Eco Campus. Beberapa permasalahan tersebut dianggap berdampak pada minat mahasiswa dalam program ITS Smart Eco Campus.

\section{TINJAUAN PUSTAKA}

\section{A. Knowledge}

Knowledge merupakan cakupan seluruh informasi akurat yang disimpan dalam memori seseorang yang sama baiknya dengan persepsi terhadap pengetahuan pada suatu hal [3]. Knowlegde dianggap sebagai persepsi seseorang terhadap produk atau program tertentu, termasuk pengalaman sebelumnya menggunakan produk atau program tersebut. Dengan demikian, knowledge dalam penelitian ini dimaksudkan pada pengetahuan mahasiswa ITS pada program ITS Smart Eco Campus.

1. Dimensi Knowledge

Knowledge dapat diketahui dari empat hal [4], antara lain:

a. Atribut

Menunjukkan tentang segala aspek fisik. Terkait demikian, atribut program ITS Smart Eco Campus dilihat dari adanya reputasi program ITS Smart Eco Campus di kalangan mahasiswa ITS.

b. Manfaat Fisik

Menunjukkan tentang dampak yang langsung dirasakan ketika seseorang berinteraksi dengan produk atau jasa yang digunakan. Terkait demikian, manfaat fisik program ITS Smart Eco Campus dapat dilihat dari adanya manfaat yang dirasakan oleh mahasiswa ketika bergabung dalam program ITS Smart Eco Campus serta pengalaman ketika mengikuti program ITS Smart Eco Campus.

c. Manfaat Psikologis

Menunjukkan tentang dampak sosial yang diperoleh seseorang ketika berinteraksi dengan produk atau jasa. Terkait demikian, manfaat psikologis diketahui dari adanya peningkatan keterampilan bersosialisasi yang dirasakan oleh mahasiswa ITS setelah mengikuti program ITS Smart Eco Campus.

d. Nilai-nilai yang diperoleh

Menunjukkan tentang nilai-nilai yang diperoleh seseorang setelah menggunakan produk atau jasa. Hal ini dapat dilihat dari adanya mahasiswa ITS yang memiliki daya saing lebih tinggi setelah mengikuti program ITS Smart Eco Campus.

\section{B. Motivasi}

Motivasi merupakan istilah yang digunakan untuk menunjukkan adanya sejumlah dorongan, keinginan, kebutuhan dan kekuatan [5]. Motivasi dianggap sebagai kesediaan untuk mengeluarkan tingkat upaya yang tinggi ke arah tujuan organisasi, yang dikondisikan oleh kemampuan upaya tersebut untuk memenuhi sesuatu kebutuhan individual. Motivasi merupakan keadaan internal seseorang yang melahirkan kekuatan, kegairahan dan dinamika serta mengarahkan tingkah laku pada tujuan. Dengan demikian dapat disimpulkan bahwa motivasi mahasiswa adalah sejumlah dorongan dan kesediaan mahasiswa untuk memenuhi kebutuhan individual.

\section{Dimensi Motivasi}

Motivasi terdiri dari tiga dimensi [6], antara lain:

a. Personal benefits 
Menunjukkan tentang bagaimana partisipasi dalam suatu kegiatan dapat mempengaruhi seseorang. Dalam penelitian ini, partisipasi mahasiswa dalam program ITS Smart Eco Campus dapat mempengaruhi mahasiswa untuk bergabung dalam program tersebut.

b. Learning opportunities

Menunjukkan bahwa motivasi seseorang untuk suatu hal atau kegiatan adalah berdasarkan pada hal atau kegiatan tersebut terikat dengan adanya peluang-peluang. Dalam penelitian ini, motivasi mahasiswa terhadap program ITS Smart Eco Campus didasarkan pada keterikatan ITS Smart Eco Campus tersebut pada peluang-peluang yang akan diperoleh mahasiswa baik di lingkup Universitas ataupun di lingkup luar.

\section{c. Community benefits}

Menunjukkan bahwa terdapat beberapa faktor dan manfaat dari lingkup komunitas atau masyarakat yang berhubungan dengan adanya kontribusi positif yang ditunjukkan oleh seseorang. Dalam penelitian ini, motivasi mahasiswa untuk bergabung dalam program ITS Smart Eco Campus karena terdapat beberapa faktor dan manfaat dari adanya program ITS Smart Eco Campus tersebut dari lingkup komunitas atau masyarakat luas.

\section{Keterlibatan}

Keterlibatan merupakan persepsi konsumen tentang pentingnya atau relevansi personal suatu objek, kejadian atau aktivitas konsumen yang melihat bahwa produk yang memiliki konsekuensi relevan secara pribadi dikatakan sebagai produk dan memiliki hubungan dengan produk tersebut [7]. Apabila keterlibatan suatu produk tinggi, seseorang akan mengalami tanggapan pengaruh yang lebih kuat seperti emosi dan perasaan yang kuat. Keterlibatan adalah status motivasi yang menggerakkan serta mengarahkan proses kognitif dan perilaku konsumen pada saat membuat keputusan. Terkait demikian, keterlibatan pada penelitian ini tampak pada keterlibatan mahasiswa ITS pada program ITS Smart Eco Campus.

1. Dimensi Keterlibatan

Keterlibatan dapat diukur dengan beberapa indikator [8] yang terdiri dari:

a. Keterlibatan Emosi

Menunjukkan minat, nilai dan emosi seseorang. Dalam hal ini, keterlibatan emosi tampak pada minat mahasiswa ITS untuk bergabung dalam program ITS Smart Eco Campus.

b. Keterlibatan Kognitif

Menunjukkan persepsi terhadap motivasi, usaha keras dan penggunaan strategi. Hal ini tampak pada, keseriusan mahasiswa ITS untuk ikut serta dalam program ITS Smart Eco Campus.

c. Keterlibatan Perilaku

Menunjukkan tentang kemauan untuk terlibat dalam pekerjaan dan mengikuti aturan. Hal ini tampak pada, kemauan mahasiswa ITS dalam ikut serta dalam semua kegiatan program ITS Smart Eco Campus dan menaati aturan dalam program ITS Smart Eco Campus.

\section{Minat}

Minat adalah suatu disposisi yang terorganisir melalui pengalaman yang mendorong seseorang untuk memperoleh objek khusus, aktivitas, pemahaman dan keterampilan untuk tujuan perhatian atau pencapaian [9]. Secara umum, minat termasuk karakteristik afektif yang memiliki intensitas tinggi. Dengan demikian, dapat disimpulkan bahwa minat merupakan kecenderungan hati yang tinggi dari seseorang terhadap sesuatu sehingga orang tersebut terdorong untuk melakukan pencapaian terhadap sesuatu tersebut.

\section{E. ITS Smart Eco Campus}

Eco campus adalah sebuah sistem manajemen lingkungan berkelanjutan yang diterapkan di lingkungan tingkat pendidikan tinggi. Selain sistem manajemen lingkungan, eco campus juga meliputi konteks program pelestarian lingkungan serta sejauh mana seluruh warga kampus dapat ikut berpartisipasi dalam program tersebut dan memanfaatkan sumber daya yang ada secara efektif dan efisien [2]. Saat ini sudah banyak kampus yang menerapkan program Eco campus, salah satunya ialah ITS dan diberi nama ITS Smart Eco Campus. ITS Smart Eco Campus memiliki lima hal utama dalam penerapannya diantaranya; peningkatan efisiensi pemakaian air bersih dan peningkatan kualitas air, peningkatan efisiensi energi, pengolahan sampah terpadu, pengembangan alat transportasi ramah lingkungan dan perlindungan keanekaragaman hayati.

\section{METODE PENELITIAN}

\section{A. Data Penelitian}

Data yang digunakan dalam penelitian ini adalah data primer dan data sekunder. Pada penelitian ini, data primer berupa hasil sebaran kuesioner secara online dan offline. Kuesioner yang disebarkan secara online dapat melalui media Google Form. Sedangkan kuesioner yang disebarkan secara offline dapat dilakukan dengan cara menyebarkan kuesioner secara langsung atau tatap muka kepada responden. Pada penelitian ini, data sekunder diperoleh dari informasi terkait jumlah mahasiswa ITS yang pernah ikut serta dalam program ITS Smart Eco Campus yang bersumber dari Sistem Informasi UP 4 (Unit Pengendalian, Pengelolaan, dan Pengawasan Program) jurnal maupun sumber referensi lain.

\section{B. Sampel Penelitian}

Penentuan sampel minimal dalam penelitian ini dilakukan menggunakan rumus Slovin dengan rumus sebagai berikut [10]:

$$
n=\frac{N}{N . d 2+1}
$$

(1)

Dimana;

$\mathrm{n}$ : Ukuran sampel

$\mathrm{N}$ : Jumlah populasi sasaran

D : Batas toleransi terhadap kesalahan pengambilan sampel karena ketidaktelitian, yaitu 5\%.

Berdasarkan perhitungan dengan rumus tersebut, maka jumlah sampel penelitian adalah:

$$
n=\frac{21038}{21038 \cdot 0,05^{2}+1}=392,5=393
$$

Berdasarkan perhitungan di atas, maka sampel penelitian dalam penelitian ini adalah 393 responden. 


\section{Kuisioner penelitian}

Kuisioner penelitian dibagi menjadi empat bagian yaitu screening, profil, pertanyaan inti, serta saran atau kritik. Skala pengukuran yang digunakan pada penelitian ini yaitu skala likert 5 poin.

\section{Variabel dan Hipotesis Penelitian}

Dalam penelitian ini yang merupakan variabel laten eksogen yaitu, Minat mahasiswa. Sedangkan variabel laten endogen yaitu, Knowledge, Motivasi dan Keterlibatan. Hipotesis dalam penelitian ini adalah sebagai berikut:

$\mathrm{H}_{1} \quad$ : Knowledge berpengaruh positif terhadap minat mahasiswa dalam program ITS Smart Eco Campus

$\mathrm{H}_{2}$ : Motivasi berpengaruh positif terhadap minat mahasiswa dalam program ITS Smart Eco Campus

$\mathrm{H}_{3} \quad$ : Keterlibatan berpengaruh positif terhadap minat mahasiswa dalam program ITS Smart Eco Campus

$\mathrm{H}_{4} \quad$ : Knowledge, motivasi dan keterlibatan secara simultan berpengaruh positif terhadap minat mahasiswa dalam program ITS Smart Eco Campus

\section{E. Analisis Regresi Linier berganda}

Analisis regresi linier berganda (multiple regression analysis) adalah satu teknik statistik yang dapat digunakan untuk menganalisa hubungan antara satu variabel dependen tunggal dan beberapa variabel independen. Rumus regresi linier berganda adalah sebagai berikut:

$$
Y=\beta_{0}+\beta_{1} X_{1}+\beta_{2} X_{2}+\beta_{3} X_{3}+e
$$

Dimana;

$\begin{array}{ll}\mathrm{Y} & : \text { Minat mahasiswa } \\ \beta_{0} & : \text { Koefisien konstanta } \\ \beta_{1}, \beta_{2} & : \text { Koefisien regresi } \\ \mathrm{X}_{1} & : \text { Knowledge } \\ \mathrm{X}_{2} & : \text { Motivasi } \\ \mathrm{X}_{3} & : \text { Keterlibatan } \\ \mathrm{e} & : \text { Error }\end{array}$

\section{ANALISIS DAN PEMBAHASAN}

\section{A. Data Hasil Penelitian}

Pengumpulan data yang diperoleh dalam penelitian ini berasal dari kuesioner yang disebarkan secara online. Pengumpulan data dilakukan mulai tanggal 20 Desember sampai 10 Januari 2019. Pengumpulan data secara online dilakukan dengan menggunakan formulir online yaitu google form yang telah dibuat. Penyebaran kuesioner online dilakukan dengan mengirimkan link ke sosial media yang dimiliki oleh penulis serta lebih lanjutnya dibantu dalam pendistribusian oleh teman-teman penulis.

\section{B. Data Screening}

Dari penyebaran google form penelitian ini direspon oleh 393 responden, dan 393 kuesioner tersebut valid dan dapat diolah, karena data sudah memenuhi kriteria sampel.

\section{Karakteristik Responden}

Karakteristik responden penelitian ini dilihat dari jenis tahu tidaknya tentang program ITS Smart Eco Campus, jenis kelamin, angkatan dan Departemen/Fakultas. Berikut karakteristik responden pada penelitian ini (Tabel 2).

\section{Uji Validitas}

Uji validitas digunakan untuk mengukur apakah instrumen yang digunakan dalam penelitian valid atau tidak. Valid berarti instrumen tersebut dapat digunakan untuk mengukur apa yang seharusnya diukur. Jika nilai korelasi antara skor butir variabel dengan total skor suatu variabel sama dengan 0,3 atau lebih (paling kecil 0,3) maka butir instrumen dinyatakan valid (Tabel 3).

$$
\text { Tabel } 2 .
$$

Karakteristik Penelitian

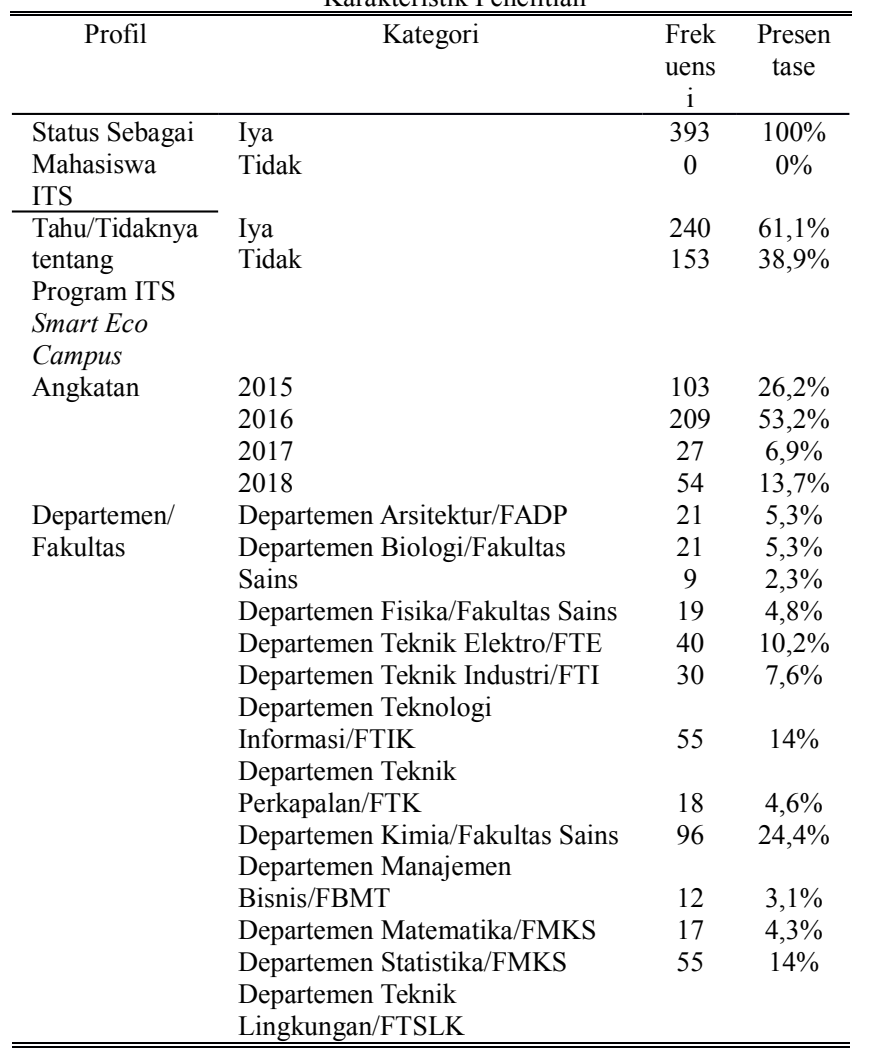

Tabel 3.

\begin{tabular}{|c|c|c|c|}
\hline Variabel & Item & $\begin{array}{c}\text { Korelasi } \\
\text { Pearson (r) }\end{array}$ & $\begin{array}{c}\text { Tingkat } \\
\text { Signifikan }\end{array}$ \\
\hline \multirow[t]{8}{*}{ Knowledge } & KNOW1 & 0,856 & 0,000 \\
\hline & KNOW2 & 0,588 & 0,000 \\
\hline & KNOW3 & 0,871 & 0,000 \\
\hline & KNOW4 & 0,737 & 0,000 \\
\hline & KNOW5 & 0,823 & 0,000 \\
\hline & KNOW6 & 0,804 & 0,000 \\
\hline & KNOW7 & 0,713 & 0,000 \\
\hline & KNOW8 & 0,771 & 0,000 \\
\hline \multirow[t]{9}{*}{ Motivasi } & MOT1 & 0,852 & 0,000 \\
\hline & MOT2 & 0,648 & 0,000 \\
\hline & MOT3 & 0,852 & 0,000 \\
\hline & MOT4 & 0,765 & 0,000 \\
\hline & MOT5 & 0,706 & 0,000 \\
\hline & MOT6 & 0,826 & 0,000 \\
\hline & MOT7 & 0,761 & 0,000 \\
\hline & MOT8 & 0,711 & 0,000 \\
\hline & MOT9 & 0,813 & 0,000 \\
\hline \multirow[t]{7}{*}{ Keterlibatan } & KET1 & 0,690 & 0,000 \\
\hline & KET2 & 0,682 & 0,000 \\
\hline & KET3 & 0,869 & 0,000 \\
\hline & KET4 & 0,889 & 0,000 \\
\hline & KET5 & 0,851 & 0,000 \\
\hline & KET6 & 0,599 & 0,000 \\
\hline & KET7 & 0,883 & 0,000 \\
\hline \multirow[t]{5}{*}{ Minat } & MIN1 & 0,916 & 0,000 \\
\hline & MIN2 & 0,876 & 0,000 \\
\hline & MIN3 & 0,916 & 0,000 \\
\hline & MIN4 & 0,745 & 0,000 \\
\hline & MIN5 & 0,390 & 0,000 \\
\hline
\end{tabular}

Hasil Uji Validitas 


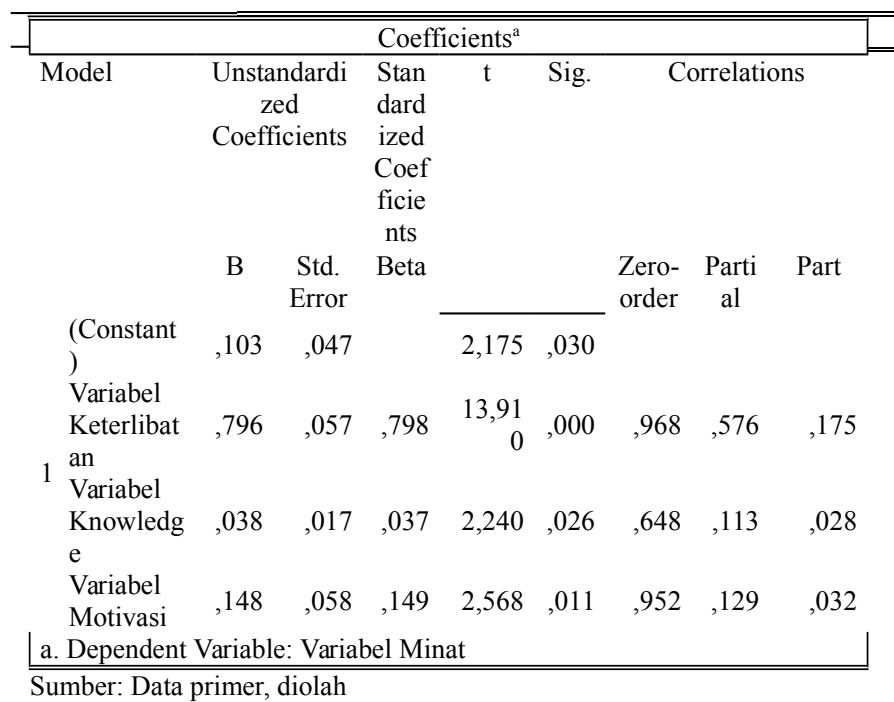

\section{E. Uji Reliabilitas}

Uji reliabilitas digunakan untuk mengukur reliabilitas dari instrumen pengukuran. Instrumen yang reliabel adalah instrumen yang bila digunakan beberapa kali untuk mengukur objek yang sama, akan menghasilkan data yang sama. Uji reliabilitas akan dilakukan menggunakan uji statistik cronbach's alpha $(\alpha)$ dengan ketentuan bahwa variabel yang diteliti dinyatakan reliabel apabila nilai cronbach's alpha $(\alpha)$ adalah di atas 0,6. Berikut hasil uji reliabilitas dalam penelitian ini:

Tabel 4.

Hasil Uji Reliabilitas

\begin{tabular}{|c|c|c|}
\hline Variabel Penelitian & Cronbach's alpha $(\alpha)$ & Keterangan \\
\hline Knowledge & 0,889 & Reliabel \\
\hline Motivasi & 0,889 & Reliabel \\
\hline Keterlibatan & 0,913 & Reliabel \\
\hline Minat & 0,875 & Reliabel \\
\hline
\end{tabular}

Sumber: Data primer, diolah

\section{F. Analisis Regresi Linier Berganda}

Regresi linier berganda digunakan untuk mengetahui hubungan kausal antara variabel tidak bebas (Y) dengan lebih dari satu variabel bebas $(\mathrm{X})$. Persamaan regresi linier berganda dalam penelitian ini yang didapat dari hasil pengolahan data dengan program SPSS adalah sebagai berikut:

Tabel 5.

Sumber: Data primer, diolah.

Hasil Analisis Regresi Linier Berganda

Dari Tabel 5. diperoleh persamaan regresi linier berganda sebagai berikut:

$\mathrm{Y}=0,103+0,038 \mathrm{X}_{1}+0,148 \mathrm{X}_{2}+0,796 \mathrm{X}_{3}$

Berdasarkan persamaan regresi linier berganda di atas dapat dijelaskan bahwa:

1. Nilai a sebesar 0,103 yang menunjukkan nilai kostanta. Artinya jika variabel bebas knowledge (X1), motivasi (X2), dan keterlibatan (X3) sama dengan nol, maka minat (Y) akan sebesar 0,103 satuan.

2. Nilai b1 sebesar 0,038 yang menunjukkan nilai koefisien knowledge (X1). Artinya jika knowledge (X1) mengalami peningkatan sebesar satu satuan, maka minat (Y) juga akan meningkat sebesar 0,038 satuan dengan asumsi besarnya variabel bebas motivasi (X2) dan keterlibatan (X3) tetap.

3. Nilai b2 sebesar 0,148 yang menunjukkan nilai koefisien motivasi (X2). Artinya jika motivasi (X2) mengalami peningkatan sebesar satu satuan, maka minat $(\mathrm{Y})$ juga akan meningkat sebesar 0,148 satuan dengan asumsi besarnya variabel bebas knowledge (X1) dan keterlibatan (X3) tetap. 4. Nilai b3 sebesar 0,796 yang menunjukkan nilai koefisien keterlibatan (X3). Artinya jika keterlibatan (X3) mengalami peningkatan sebesar satu satuan, maka minat (Y) juga akan meningkat sebesar 0,796 satuan dengan asumsi besarnya variabel knowledge (X1) dan motivasi (X2) tetap.

\section{G. Uji F}

Uji F digunakan untuk membuktikan "Knowledge, Motivasi dan Keterlibatan berpengaruh secara simultan terhadap Minat Mahasiswa dalam Program ITS Smart Eco Campus". Berikut hasil pengolahan data yang diperoleh pada perhitungan untuk uji $\mathrm{F}$ :

Tabel 6.

Pengujian Hipotesis dengan Uji F ANOVA ${ }^{\mathrm{a}}$

\begin{tabular}{|c|c|c|c|c|c|}
\hline "Model & $\begin{array}{l}\text { Sum of } \\
\text { Squares }\end{array}$ & $\overline{\overline{D f f}}$ & $\begin{array}{l}\text { Mean } \\
\text { Square }\end{array}$ & $\overline{\bar{F}}$ & Sig. \\
\hline Regression & 163,600 & 3 & 54,533 & 1987,910 &, $000^{\mathrm{b}}$ \\
\hline 1 Residual & 10,671 & 389 & ,027 & & \\
\hline Total & 174,271 & 392 & & & \\
\hline
\end{tabular}

a. Dependent Variable: Variabel Minat

b. Predictors: (Constant), Variabel Motivasi, Variabel

Knowledge, Variabel Keterlibatan

Sumber: Data primer, diolah

Hasil pengujian diperoleh nilai $F$ sebesar 1987,910 dengan nilai signifikan yang diperoleh 0,000 di mana nilai tersebut lebih kecil dari 0,05. Dengan demikian dapat dijelaskan bahwa terdapat pengaruh signifikan secara simultan antara variabel knowledge, motivasi dan keterlibatan terhadap minat. Oleh karena itu, hipotesis yang menyatakan bahwa "Knowledge, Motivasi dan Keterlibatan berpengaruh secara simultan terhadap Minat Mahasiswa dalam Program ITS Smart Eco Campus" telah terbukti.

\section{H. Uji t}

Uji t dalam penelitian ini menggunakan ketentuan sebagai berikut:

1. Jika signifikan hasil $>0,05$ maka hipotesis ditolak.

2. Jika signifikan hasil $<0,05$ maka hipotesis diterima

Tabel 7.

Hasil Uji t

\begin{tabular}{lcc}
\hline \hline \multicolumn{1}{c}{ Variabel Bebas } & $\mathrm{T}$ & Signifikan \\
\hline Knowledge $\left(\mathrm{X}_{1}\right)$ & 2,240 & 0,026 \\
Motivasi $\left(\mathrm{X}_{2}\right)$ & 2,568 & 0,011 \\
Keterlibatan $\left(\mathrm{X}_{3}\right)$ & 13,910 & 0,000 \\
\hline \hline
\end{tabular}

Sumber: Data primer, diolah

Pada Tabel 7 diketahi bahwa nilai t hitung untuk variabel knowledge $\left(\mathrm{X}_{1}\right)$ sebesar 2,240 dengan nilai signifikan yang diperoleh 0,026; untuk variabel motivasi $\left(\mathrm{X}_{2}\right)$ sebesar 2,568 dengan nilai signifikan yang diperoleh 0,011 ; dan untuk variabel keterlibatan $\left(\mathrm{X}_{3}\right)$ sebesar 13,910 dengan nilai signifikan yang diperoleh 0,000 . Hal tersebut menunjukkan bahwa variabel knowledge $\left(\mathrm{X}_{1}\right)$, motivasi $\left(\mathrm{X}_{2}\right)$ dan keterlibatan $\left(\mathrm{X}_{3}\right)$ memiliki nilai signifikan $<0,05$ maka hipotesis diterima. Dengan demikian dapat dikatakan bahwa knowledge, motivasi dan keterlibatan secara parsial berpengaruh terhadap minat mahasiswa dalam program ITS Smart Eco Campus 


\section{Pembahasan Hipotesis}

a. Hipotesis 1 (Pengaruh Positif Knowledge terhadap Minat Mahasiswa dalam Program ITS Smart Eco Campus)

Hasil penelitian menunjukkan bahwa nilai thitung untuk variabel knowledge $\left(\mathrm{X}_{1}\right)$ sebesar 2,240 dengan nilai signifikan yang diperoleh 0,026 . Nilai signifikansi yang diperoleh lebih kecil dari 0,05. Hal ini menunjukkan bahwa knowledge berpengaruh terhadap minat mahasiswa dalam program ITS Smart Eco Campus. Nilai t hitung yang ditunjukkan menunjukkan angka positif. Terkait demikian, terdapat pengaruh positif knowledge terhadap minat mahasiswa dalam program ITS Smart Eco Campus.

Knowledge dianggap sebagai sebuah pengetahuan umum tentang fakta, konsep dan hubungan. Dalam hal ini knowledge berkaitan dengan program ITS Smart Eco Campus. Hasil penelitian ini didukung dengan hasil yang menunjukkan bahwa pengetahuan berpengaruh terhadap minat [11].

b. Hipotesis 2 (Pengaruh Positif Motivasi terhadap Minat Mahasiswa dalam Program ITS Smart Eco Campus)

Hasil penelitian menunjukkan bahwa nilai t hitung untuk variabel motivasi $\left(\mathrm{X}_{2}\right)$ sebesar 2,568 dengan nilai signifikan yang diperoleh 0,011 . Nilai signifikansi yang diperoleh lebih kecil dari 0,05. Hal ini menunjukkan bahwa motivasi berpengaruh terhadap minat mahasiswa dalam program ITS Smart Eco Campus. Nilai t hitung yang ditunjukkan menunjukkan angka positif. Terkait demikian, terdapat pengaruh positif motivasi terhadap minat mahasiswa dalam program ITS Smart Eco Campus.

Agar seseorang memiliki minat, diperlukan suatu dorongan dari dalam diri seseorang tersebut sehingga tujuan dari hal atau kegiatan yang dilakukan oleh seseorang tersebut dapat tercapai. Hasil penelitian ini didukung oleh penelitian yang menunjukkan bahwa minat mahasiswa, diketahui bahwa terdapat beberapa hal yang mempengaruhi minat mahasiswa di mana salah satunya adalah motivasi [6]. Selain itu juga didukung penelitian lain yang menunjukkan bahwa minat mahasiswa dalam mengambil program disebabkan oleh adanya dorongan dari mahasiswa untuk mencari tahu tentang informasi program dan harapan terkait dengan program [9].

c. Hipotesis 3 (Pengaruh Keterlibatan terhadap Minat

Mahasiswa dalam Program ITS Smart Eco Campus)

Hasil penelitian menunjukkan bahwa nilai t hitung untuk variabel keterlibatan $\left(X_{3}\right)$ sebesar 13,910 dengan nilai signifikan yang diperoleh 0,000 . Nilai signifikansi yang diperoleh lebih kecil dari 0,05. Hal ini menunjukkan bahwa keterlibatan berpengaruh terhadap minat mahasiswa dalam program ITS Smart Eco Campus. Nilai t hitung yang ditunjukkan menunjukkan angka positif. Terkait demikian, terdapat pengaruh positif keterlibatan terhadap minat mahasiswa dalam program ITS Smart Eco Campus.

Hasil penelitian ini didukung oleh penelitian yang menunjukkan bahwa keterlibatan adalah minat atau bagian motivasional yang dapat timbul karena terdapat stimulus atau situasi tertentu [12]. Keterlibatan seseorang terhadap lingkungan dianggap dapat mempengaruh minat orang tersebut pada hal yang mengandung unsur lingkungan. Keterlibatan seseorang dalam lingkungan berhubungan erat dengan karakteristik seseorang dan pengetahuan yang dimiliki terkait dengan lingkungan yang pada akhirnya mempengaruhi orang tersebut untuk menentukan perilaku yang dilakukan selanjutnya. d. Hipotesis 4 (Pengaruh Simultan Antara Knowledge, Motivasi dan Keterlibatan terhadap Minat Mahasiswa dalam Program ITS Smart Eco Campus)

Hasil penelitian menunjukkan bahwa nilai $\mathrm{F}$ sebesar 1987,910 dengan nilai signifikan yang diperoleh 0,000 di mana nilai tersebut lebih kecil dari 0,05. Dengan demikian dapat dijelaskan bahwa terdapat pengaruh signifikan secara simultan antara variabel knowledge, motivasi dan keterlibatan terhadap minat. Oleh karena itu, hipotesis yang menyatakan bahwa "knowledge, motivasi dan keterlibatan berpengaruh secara simultan terhadap minat mahasiswa dalam program ITS Smart Eco Campus" telah terbukti.

\section{KESIMPULAN}

Berdasarkan pengolahan dan analisisi data yang telah dilakukan, terdapat beberapa poin yang menjadi kesimpulan dari penelitian ini, yaitu:

1. Hasil penelitian menunjukkan bahwa nilai t hitung untuk variabel knowledge $\left(\mathrm{X}_{1}\right)$ sebesar 2,240 dengan nilai signifikan yang diperoleh 0,026 . Nilai signifikansi yang diperoleh lebih kecil dari 0,05. Hal ini menunjukkan bahwa knowledge berpengaruh terhadap minat mahasiswa dalam program ITS Smart Eco Campus. Nilai t hitung yang ditunjukkan menunjukkan angka positif. Terkait demikian, terdapat pengaruh positif knowledge terhadap minat mahasiswa dalam program ITS Smart Eco Campus. Knowledge dianggap sebagai sebuah pengetahuan umum tentang fakta, konsep dan hubungan. Dalam hal ini knowledge berkaitan dengan program ITS Smart Eco Campus.

2. Hasil penelitian menunjukkan bahwa nilai t hitung untuk variabel motivasi $\left(\mathrm{X}_{2}\right)$ sebesar 2,568 dengan nilai signifikan yang diperoleh 0,011 . Nilai signifikansi yang diperoleh lebih kecil dari 0,05. Hal ini menunjukkan bahwa motivasi berpengaruh terhadap minat mahasiswa dalam program ITS Smart Eco Campus. Nilai t hitung yang ditunjukkan menunjukkan angka positif. Terkait demikian, terdapat pengaruh positif motivasi terhadap minat mahasiswa dalam program ITS Smart Eco Campus. Hal ini menunjukkan bahwa minat mahasiswa dalam mengambil program disebabkan oleh adanya dorongan dari dalam diri mahasiswa itu sendiri untuk mencari tahu tentang informasi program dan harapan terkait dengan program.

3. Hasil penelitian menunjukkan bahwa nilai $t$ hitung untuk variabel keterlibatan $\left(\mathrm{X}_{3}\right)$ sebesar 13,910 dengan nilai signifikan yang diperoleh 0,000. Nilai signifikansi yang diperoleh lebih kecil dari 0,05. Hal ini menunjukkan bahwa keterlibatan berpengaruh terhadap minat mahasiswa dalam program ITS Smart Eco Campus. Nilai t hitung yang ditunjukkan menunjukkan angka positif. Terkait demikian, terdapat pengaruh positif keterlibatan terhadap minat mahasiswa dalam program ITS Smart Eco Campus. Hal tersebut menunjukkan bahwa keterlibatan merupakan motif yang membuat seseorang tertarik atau ingin membeli, terjun langsung atau terlibat langsung pada suatu produk serta konsumsi jasa yang ditawarkan. Keterlibatan seseorang dalam sebuah lingkungan erat hubungannya dengan karakteristik seseorang dan pengetahuan yang dimiliki terkait dengan lingkungan yang dia inginkan.

4. Knowledge, motivasi dan keterlibatan secara bersamasama berpengaruh terhadap minat mahasiswa dalam program ITS Smart Eco Campus. 


\section{DAFTAR PUSTAKA}

[1] UI Green Metrics, "UI Green Metrics," 2017. [Online]. Available: http://greenmetric.ui.ac.id/detailregion2017/?region=Asia.

[2] Institut Teknologi Sepuluh Nopember, "ITS Media Center," 2014 [Online]. Available: https://www.its.ac.id/id/its-kampus-smarteco/.

[3] D. Hertita, Setiap Pebisnis Harus Punya Buku Ini. Jakarta: Elex Media Komputindo, 2018.

[4] R. Manuarang and M. Mawardi, "Pengaruh Product Knowledge Terhadap Purchase Intention (Survei Pada Pengunjung Toko Buku Ub Press, Kota Malang)," J. Adm. Bisnis, vol. 55, no. 3, pp. 41-47, 2018.

[5] H. Riniwati, Manajemen Sumberdaya Manusia: Aktivitas Utama dan Pengembangan SDM. Malang: Universitas Brawijaya Press, 2016.

[6] R. D. Young, K. Scheuer, J. Roush, and K. Kozeleski, "Student Interest in Campus Community Gardens: Sowing the Seeds for Direct Engagement with Sustainabilit," 2016.
[7] F. Rangkuti, Riset Pemasaran. Jakarta: Gramedia Pustaka Utama, 2010.

[8] I. Dharmayana, Masrun, A. Kumara, and Y. Wirawan, "Keterlibatan Siswa (Student Engagement) sebagai Mediator Kompetensi Emosi dan Prestasi Akademik," J. Psikol., vol. 39, no. 1, pp. 76-94, 2012.

[9] Surifah, E. Mustiati, M. Syaifullah, and A. N. Bowo, "Pengaruh Motivasi terhadap Minat Mahasiswa Mengikuti Pendidikan Profesi Akuntansi," J. Kependidikan, vol. 46, no. 2, pp. 246-258, 2016.

[10] Sugiyono, Metode Penenlitian Kuantitatif, Kualitatif dan R\&D. Bandung: Alfabeta, 2014.

[11] T. Tan, Teaching is an Art: Maximize Your Teaching. Yogyakarta: Deepublish, 2017.

[12] P. Budiani and Widiartanto, "Pengaruh Atribut Toko dan Fashion Involvement terhadap Keputusan Pembelian Konsumen (Studi Kasus Pada Matahari Department Store Paragon Mall Semarang)," J. Soc. Polit. Sci., pp. 1-10, 2015. 